\title{
TRPM7 Gene
}

National Cancer Institute

\section{Source}

National Cancer Institute. TRPM7 Gene. NCI Thesaurus. Code C98058.

This gene plays a role in both ion transport and protein phosphorylation. 